\title{
VOLCANO HAZARDS PROGRAM IN THE UNITED STATES
}

\author{
ROBERT I. TILLING ${ }^{1}$ and ROY A. BAILEY ${ }^{2}$ \\ ${ }^{1}$ U.S. Geological Survey, MS-95I, National Center, Reston, Virginia, U.S.A. \\ ${ }^{2}$ U.S. Geological Survey, 345 Middlefield Road, Menlo Park, California. U.S.A. \\ (Received January 10, 1985)
}

\begin{abstract}
Tilling, R. I. and Bailey, R. A., 1985. Volcano hazards program in the United States, Journal of Geodynamics, 3: 425-446.

Volcano monitoring and volcanic-hazards studies have received greatly increased attention in the United States in the past few years. Before 1980, the Volcanic Hazards Program was primarily focused on the active volcanoes of Kilauea and Mauna Loa, Hawaii, which have been monitored continuously since 1912 by the Hawaiian Volcano Observatory. After the reawakening and catastrophic eruption of Mount St. Helens in 1980, the program was substantially expanded as the government and general public became aware of the potential for eruptions and associated hazards within the conterminous United States. Integrated components of the expanded program include: volcanic-hazards assessment; volcano monitoring; fundamental research; and, in concert with federal, state, and local authorities, emergency-response planning.

In 1980 the David A. Johnston Cascades Volcano Observatory was established in Vancouver. Washington, to systematically monitor the continuing activity of Mount St. Helens, and to acquire baseline data for monitoring the other, presently quiescent, but potentially dangerous Cascade volcanoes in the Pacific Northwest. Since June 1980, all of the eruptions of Mount St. Helens have been predicted successfully on the basis of seismic and geodetic monitoring.

The largest volcanic eruptions, but the least probable statistically, that pose a threat to western conterminous United States are those from the large Pleistocene-Holocene volcanic systems, such as Long Valley caldera (California) and Yellowstone caldera (Wyoming), which are underlain by large magma chambers still potentially capable of producing catastrophic caldera-forming eruptions. In order to become better prepared for possible future hazards associated with such historically unprecedented events, detailed studies of these, and similar, large volcanic systems should be intensified to gain better insight into caldera-forming processes and to recognize, if possible, the precursors of caldera-forming eruptions.
\end{abstract}

\section{INTRODUCTION}

The United States has over 150 volcanoes that have erupted one or more times during the Holocene (Simkin and others, 1981); most of these are located in Alaska, Hawaii, and the Cascade Range of the Pacific Northwest, 
but others are widely distributed elsewhere in the western conterminous United States. The oceanic volcanoes of Hawaii typically erupt nonexplosively and thus generally pose greater hazards to property than to life. However, large, explosive, hydromagmatic eruptions are known to have occurred rarely in Hawaii, and they can not be dismissed entirely (Decker and Christiansen, 1984). The convergent plate-boundary volcanoes of Alaska characteristically erupt explosively, but, because of their remoteness, they pose relatively little danger compared to the destruction wreaked by similar volcanoes in densely populated regions, such as Japan, Indonesia, and the Philippines. Comparatively, the composite volcanoes of the Cascade Range perhaps pose the greatest volcanic hazards in the U.S.-both at present and in the foreseeable future-because of their explosive nature and proximity to populated and cultivated areas in Washington, Oregon, and California. But over the long term, the younger pre-Holocene volcanic systems of the western conterminous United States potentially pose far

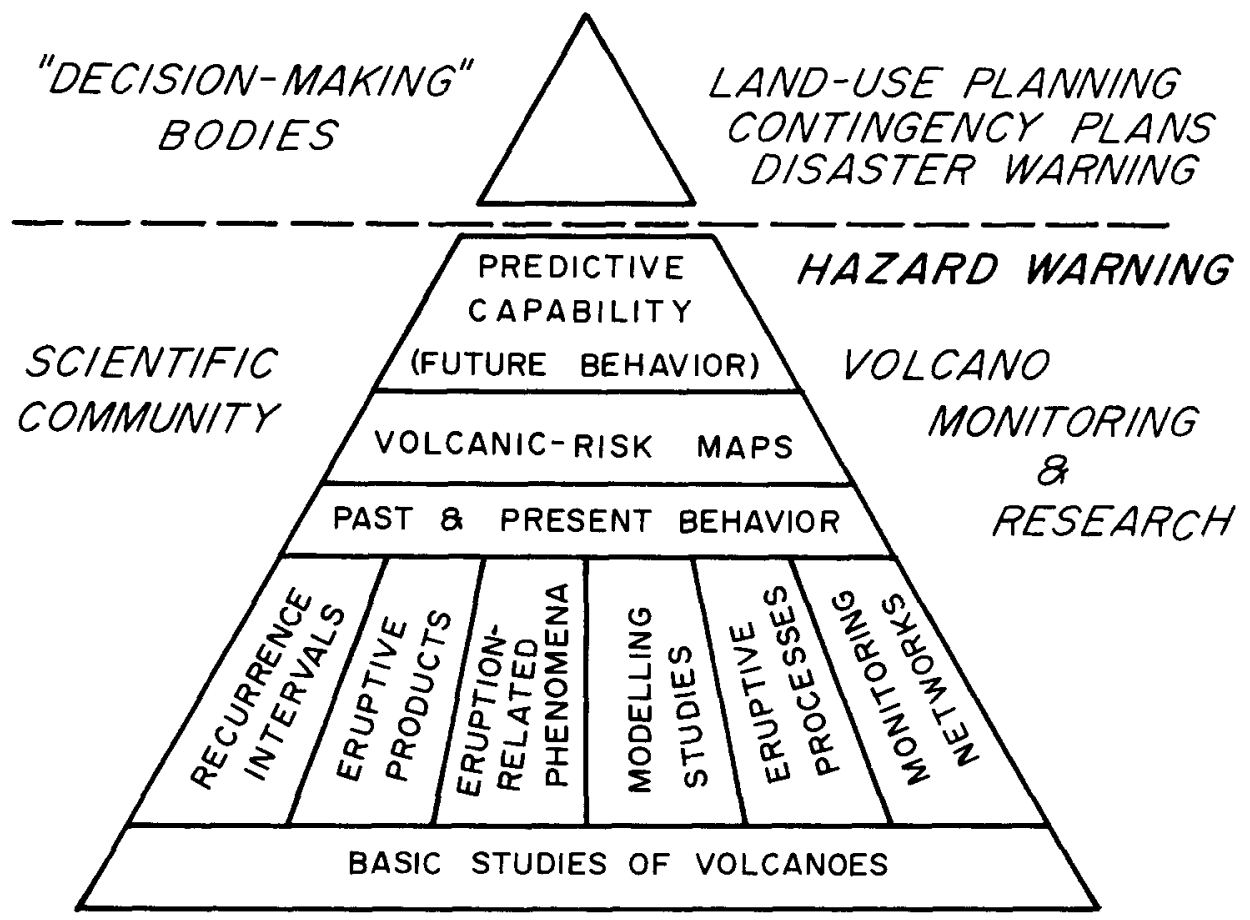

Fig. 1. Schematic illustrating that any effective program of mitigation of volcanic hazards must be built on a strong foundation of basic and specialized studies of volcanoes. The separation of the apex from the rest of the triangle reflects the fact that the civil authorities do not make decisions regarding hazards mitigation on scientific information alone, but must also consider administrative and socio-economic factors. 
greater threats, should they become reactivated and erupt cataclysmically (Smith and Luedke, 1984).

The ultimate goal of the United States Volcano Hazards Program is the mitigation of volcanic and associated hazards. However, progress toward attainment of this goal must be premised on a strong foundation of longterm basic and specialized studies of volcanoes (Fig. 1) that contribute to an improved understanding of volcanic phenomena in general, and of eruption processes and mechanisms in particular. This paper summarizes the current volcano-monitoring and related studies being conducted under the U.S. Volcano Hazards Program and updates the report presented at the 27th International Geological Congress (Tilling and Bailey, 1984a, b).

\section{HISTORICAL BACKGROUND}

Studies of U.S. volcanoes have been conducted for many decades by scientists of the U.S. Geological Survey (USGS) as well as by university research groups. Because of the high frequency of eruptions and relatively easy access for safe study, Kilauea and Mauna Loa Volcanoes, Hawaii, have received much attention from volcanologists. In 1911, two years after a stimulating lecture by visiting Thomas A. Jaggar, of the Massachusetts Institute of Technology, a group of Hawaiian residents founded the Hawaiian Volcano Research Association (HVRA). In January 1912, with support from HVRA and the Whitney Foundation, the Hawaiian Volcano Observatory (HVO) was established by Dr. Jaggar for the systematic monitoring of volcanoes in Hawaii. Administered by various Federal agencies, including the USGS, the Weather Bureau, and the National Park Service, between 1919 and 1948, HVO has been operated continuously by the USGS since 1948. During the 70 years of comprehensive study of Hawaiian volcanism, the HVO staff and visiting scientists pioneered and refined many of the commonly used volcano-monitoring techniques now applied worldwide.

Prior to the reawakening of Mount St. Helens in 1980 (Lipman and Mullineaux, 1981; Foxworthy and Hill, 1982), only a few scientists, principally within the USGS, perceived any serious potential for volcanic eruptions in the United States, excluding Alaska and Hawaii. Consequently, even though a few limited volcanic-hazards studies were begun, the Cascade volcanoes received less attention than the Hawaiian volcanoes. The apparent complacency about potential eruptive activity of the Cascade volcanoes is understandable in view of the fact that, except for the eruptions at Lassen Peak (California) during 1914-17, no significant eruptions occurred in the conterminous United States during the 20th century. Nevertheless, with 
support from HVO, an additional small observatory was established in 1926 at Mineral, California, to monitor the Lassen Peak activity, and another in 1927 at Kodiak Island, Alaska. Both of these were modest operations that had to be abandoned during the Great Depression of the 1930's, which HVO itself only barely survived by severe retrenchment.

In the late 1950's, studies on the eruption frequencies and the nature and distribution of the eruptive products of some of the Cascade volcanoes were begun. As more became known of the eruptive histories of these volcanoes, the prevailing complacency gave way to increased concern. As early as May 1968, the late Dr. William T. Pecora, USGS Director at that time, was quoted in the Christian Science Monitor as being “...especially worried about

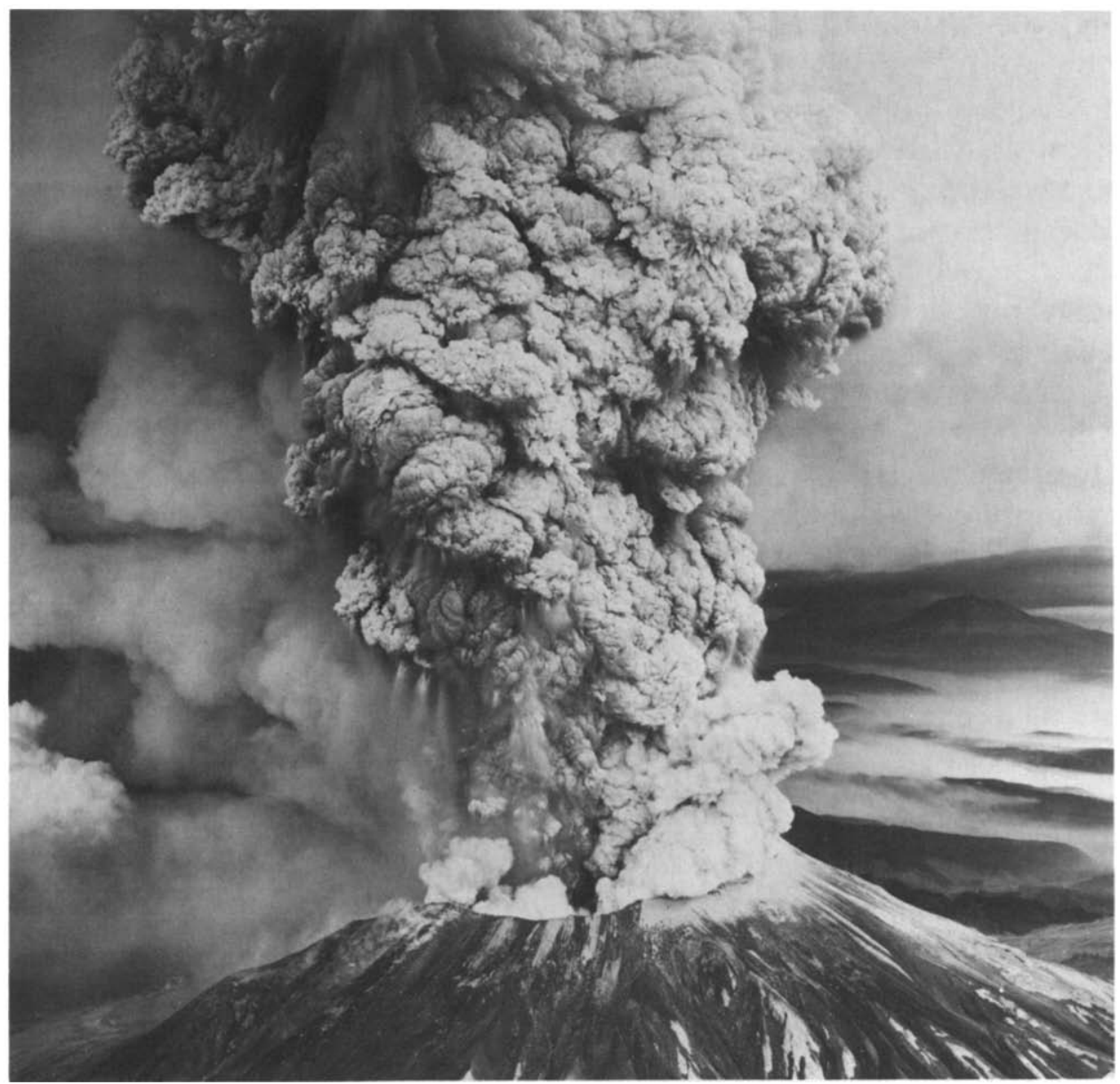

Fig. 2. The climactic eruption of Mount St. Helens on May 18, 1980 about 5 hours after the beginning of activity. The plume reached an altitude of about $24 \mathrm{~km}$. (Photograph by Austin Post). 
snow-covered Mount St. Helens." Crandell and others (1975) concluded that Mount St. Helens is the volcano in the conterminous United States most likely to reawaken and to erupt, "...perhaps before the end of the century." This prophetic conclusion was followed by a more detailed analysis of the types, magnitudes, and areal extents of potential volcanic hazards that might be expected from Mount St. Helens (Crandell and Mullineaux, 1978). These two publications contain one of the most accurate forecasts to date of a violent geologic event. Despite the specific concern about Mount St. Helens and subsequent general volcanic-hazards assessments of other Cascade volcanoes (Crandell and Mullineaux, 1975, 1978; Crandell and others, 1979), attempts by the USGS to obtain funding for increased study and surveillance of the Cascade volcanoes were unsuccessful.

1980 marked a turning point in the U.S. Volcano Hazards Program. The catastrophic eruption of Mount St. Helens (Fig. 2) and related events in May of 1980-the worst volcanic disaster in the recorded history of the United States- heightened public and official awareness (Wesson, 1980) and provided a tragic reminder that the active volcanoes of the U.S. are not restricted to Alaska and Hawaii. In the summer of 1980, the USGS Volcano Hazards Program was expanded substantially and included the establishment of a permanent, regional facility at Vancouver, Washington, to maintain systematic surveillance of Mount St. Helens' continuing activity. On May 18, 1982, the Vancouver facility was formally dedicated as the David A. Johnston Cascades Volcano Observatory, in memory of the USGS volcanologist killed at Mount St. Helens two years earlier. The Cascades Volcano Observatory (CVO) not only closely monitors Mount St. Helens, but it also serves as the headquarters for monitoring other volcanoes of the Cascade Range (Brantley and Topinka, 1984).

\section{GENERAL ASSESSMENT OF ERUPTION POTENTIAL OF U.S. VOLCANOES}

A fundamental starting point in any assessment of the potential for future eruptions of a volcano is its past record of eruption frequency or periodicity. Present data on the eruption periodicity of U.S. volcanoes are inadequate but nevertheless permit a general assessment of their eruption potential. The potentially active U.S. volcanoes have been assigned (Bailey and others, 1983 ) to the following three groups in relative order of decreasing eruption potential (Figure 3):

Group 1-volcanoes that have eruption periodicities of 100-200 years and/or have erupted within the past 200-300 years.

Group 2-volcanoes that appear to have eruption periodicities of 1,000 years or greater and last erupted 1,000 or more years ago. 
Group 3-volcanic systems that last erupted in pre-Holocene times, but beneath which still exists shallow magma reservoirs (as shown by geological and geophysical evidence).

Some of the volcanoes in Groups 1 and 2-such as Mono-Inyo Craters, Lassen Peak, Mount Shasta, Three Sisters, Newberry, and Medicine Lake, whose eruptive products have evolved toward relatively silicic compositions (McBirney, 1968; 1978) have the potential for cataclysmic eruption like that of Mt. Mazama which erupted about 6,600 years ago to form Crater Lake. Within recorded history, the world has not experienced an eruption of the magnitude of the Mt. Mazama event, which probabely ejected at least twice the volume of material erupted during the 1815 eruption of Tambora (Sumbawa, Indonesia), the largest well-recorded historic volcanic event.

A major eruption of any one of the volcanic systems of Group 3 could be orders of magnitude larger than even that of the Mt. Mazama eruption. For example, three enormous caldera-forming eruptions have taken place at Yellowstone within the past 2 m.y. years (Christiansen, 1984). Seismic and other geophysical evidence strongly suggests that a large magma reservoir

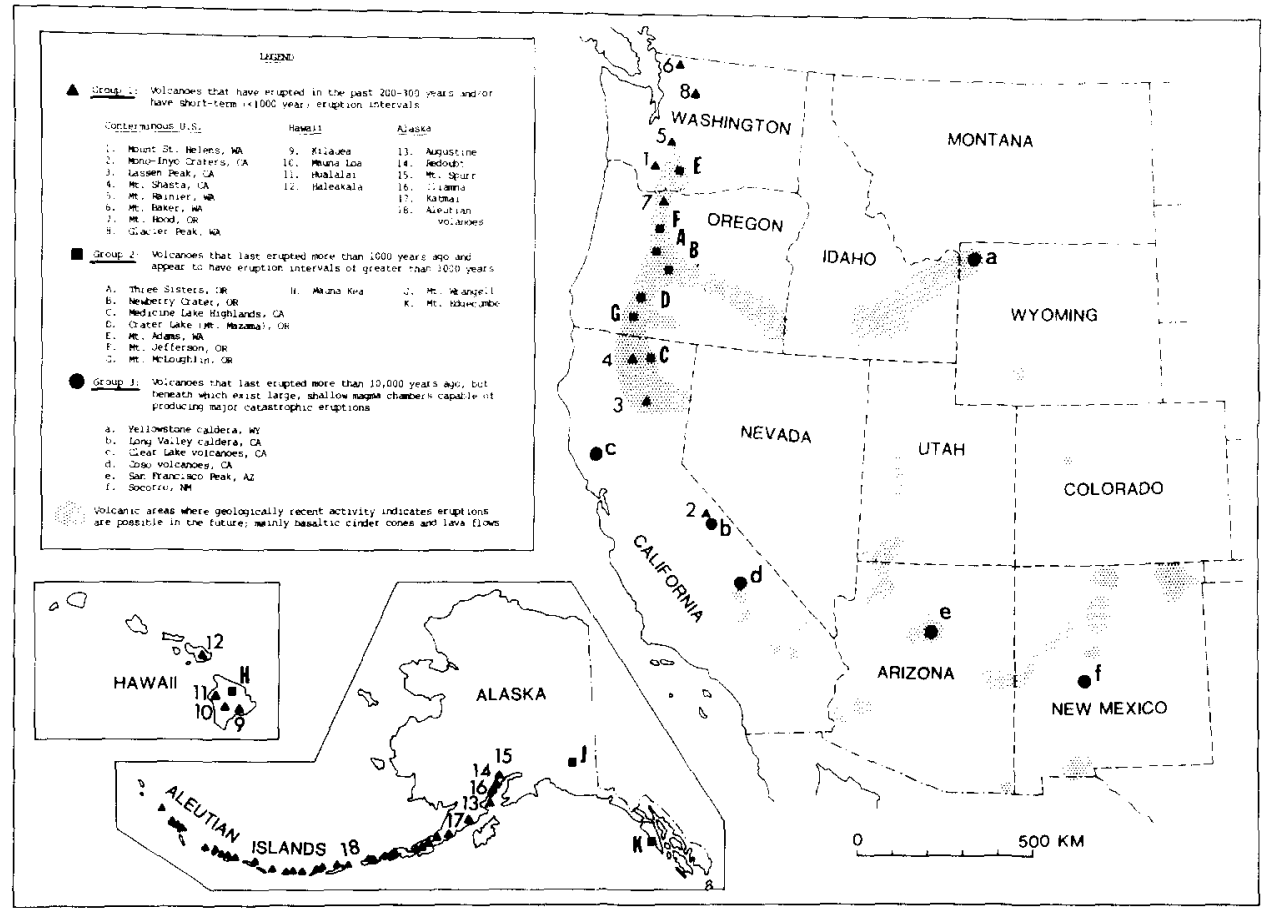

Fig. 3. Location of active volcanoes and volcanic areas in the United States. Volcano Groups 1, 2, and 3 are listed in inset in relative order of decreasing eruption potential. (Modified from Tilling and Bailey, 1984b). 
underlies the Yellowstone region at depths as shallow as $8 \mathrm{~km}$ (Eaton and others, 1975; Iyer, 1975; Smith and Christiansen, 1980). Furthermore, the floor of the present Yellowstone caldera has bulged upward $70 \mathrm{~cm}$ in the past 50 years and is probably continuing to deform (Pelton and Smith, 1979). In order to document continuing changes, in 1983 the USGS increased its seismic and geodetic monitoring effort there. Are there other volcanic terranes in the western conterminous U.S. undergoing similar magma-related deformation at comparable rates? Sufficient data are not yet available to answer this question.

The assessment of eruption potential of U.S. volcanoes by Bailey and others (1983), although preliminary and based on limited information, emphasizes the need to acquire fundamental geologic, geophysical, and geochemical data essential for deciphering the eruptive histories and behavior of active or potentially active volcanoes. Such data are needed not only to quantify the assessment of eruption potential of individual volcanoes or groups of related volcanoes, but also to design or modify volcanomonitoring networks, both operational and planned.

PROGRAM GOALS, OBJECTIVES, AND COMPONENTS

The Hawaiian Volcano Research Association, which was instrumental in founding the Hawaiian Volcano Observatory in 1912, had in its logo the motto "Ne plus haustae aut obrutea urbes" ("No more shall the cities be destroyed")-perhaps one of the earliest explicit statements of the underlying rationale for conducting research on volcanoes. Nonetheless, not until the late 1960's did studies of volcanoes become a specific government program, with a budget explicitly and primarily justified in terms of hazards mitigation.

In 1974, the U.S. Congress passed the Disaster Relief Act of 1974 (PL 93-288), which assigned to the U.S. Geological Survey the responsibility of providing timely warnings of volcanic and related hazards. The ultimate goal of the Volcano Hazards Program is “...to reduce the loss of life, property, and natural resources that can result from volcanic eruptions and related consequences." (Bailey and others, 1983, p. 14). Principal objectives of the program are to:

1. Assess the volcanic and related hydrologic hazards of volcanoes in the U.S.

2. Systematically monitor active and potentially active volcanoes.

3. Conduct fundamental research on volcanic and related phenomena.

4. Provide hazards information to other Federal, state, and local agencies and officials for land-use and emergency-response planning. 
Accordingly, the current Volcano Hazards Program consists of four main components designed to meet the above-listed objectives. The activities within these components are briefly summarized below.

\section{Volcanic-hazards assessment}

Volcanic-hazards assessments are specialized investigations of the age(s), nature, and distribution of eruptive products and events that can be used to reconstruct previous eruptive history and behaviour of a volcano. Examples of such assessments include those for Glacier Peak (Beget, 1982, 1983), Mt. Rainier (Crandell and Mullineaux, 1967), Mt. Baker (Hyde and Crandell, 1978), Mt. Hood (Crandell, 1980), and Mt. Shasta (Miller, 1980). An important purpose of these studies is to recognize the volcano's past eruptive pattern and periodicity, which in turn provide the best, and often only, basis for understanding present behavior and for forecasting possible future activity. Inverting the widely known and used geological dictum, Swanson (1982, p. 198) has stated "...the past is a key to the present (and future)!"

Modern hazard-assessment studies include the analysis of dangers directly linked to eruptive activity (pyroclastic flows, directed blasts, explosions, tephra fallout, lava flows, collapses avalanches, etc.) as well as of the hydrologic phenomena commonly associated with such volcanic activity (mud flows, floods, erosion, stream-channel modification, etc.). Another important aspect of hazards assessment is the determination of risk to existing and proposed civil works, such as bridges, roads, power plants, and water and sewer systems.

Hazards assessments are available for the islands of Hawaii (Mullineaux and Peterson, 1974), Oahu (Crandell, 1985), and Maui (Crandell, 1983), a number of the Cascade volcanoes, for Augustine Volcano, Alaska, (Kienle and Swanson, 1983) and for the Long Valley caldera California, (Miller and others, 1982). It must be emphasized that most of these assessments are preliminary and based on current knowledge; the assessment process includes continual or periodic updating as new data are obtained and interpreted. Also, studies are in progress to refine the methodology of volcanichazards assessment (e.g., Newhall, 1982). Such volcanic-hazards studies not only provide the basis for determining the eruption potential of the U.S. volcanoes (Figure 3), but also furnish guidance in establishing priorities for the development and /or reconfiguration of volcano-monitoring networks and for the type of fundamental research needed to understand their activity. Thus, volcanic-hazards assessments fill both a critical long-term need by providing information essential for land-use planning and for 
preparation of emergency-response plans, as well as short-term guidance for the development and implementation of the other components of the Volcano Hazards Program.

\section{Volcano Monitoring}

Systematic monitoring-visual and instrumental-of a volcano provides the day-to-day data on its state of activity. A key goal of the volcano-monitoring component of the Volcano Hazards Program is to establish seismic, ground-deformation, geoelectric, geomagnetic, geochemical, and hydrologic monitoring systems on all active and potentially active volcanoes to detect and track real-time changes that might foretell impending eruptive activity. The information from such monotoring systems enables the USGS to provide: 1. on active volcanoes, short-term warnings of future eruptive activity (lead times of days or hours); 2. on long-studied and adequately instrumented potentially active volcanoes, estimates of the time, location, nature, and possibly magnitude of impending or future eruptions; and 3. up-to-date information needed by public-safety officials to implement emergency-response plans, or in the longer term to develop sensible landuse plans for areas prone to volcanic hazards.

At present, the most comprehensive volcano monitoring in the U.S. is done by the two volcano observatories operated by the U.S. Geological Survey. The Hawaiian Volcano Observatory (HVO), which is located on the rim of Kilauea caldera and has a staff of about 25 scientists and technicians, focuses on Kilauea and Mauna Loa, two of the most active volcanoes in the world, but also maintains surveillance of the potentially active volcanoes of Hualalai, Mauna Kea, and Haleakala. The Cascades Volcano Observatory (CVO) intensively monitors the continuing activity at Mount St. Helens and serves as the base for monitoring and acquisition of intermittent baseline measurements on the other, currently less active but potentially dangerous, Cascade volcanoes. The present staff of CVO numbers about 60 and includes both volcanological and hydrologic specialists. Both HVO and $\mathrm{CVO}$, in addition to their volcano-monitoring functions, also serve as centers for the training of volcanologists, and for research and development of new monitoring techniques and instruments.

A few of the more notable accomplishments of the volcano monitoring program include: 1. correct prediction of all eruptions of Mount St. Helens since June 1980 (Swanson, 1983; Swanson and others, 1983)-a remarkable record considering the relative youth of the science of volcanology; 2. forecast of the April 1982 eruption of Kilauea (the first since November 1979), as well as the September 1982 and the January 1983 eruptions, primarily on the basis of microearthquake and ground-deformation 
monitoring; and 3. establishment since 1980 of baseline geodetic and gravimeter networks on most of the potentially dangerous Cascade volcanoes. The basis, methodologies, and case histories of the successful predictions at Mount St. Helens, and of the forecast of the 1984 Mauna Loa eruption, are discussed in Swanson and others (1984) and Decker and others $(1983,1984)$ respectively.

Particulary significant are the recent advances made in geochemical monitoring of volcanoes. At Kilauea, volcanic gases currently are monitored at 25 sites, by sampling at least twice a week and analyzing chromatographically more than 10 different species (Grenland, 1984). Baseline data on the composition of fluids from fumaroles and hot springs also are periodically obtained from Lassen Peak, Mount Shasta, Mount Hood, Mount Baker, and Glacier Peak volcanoes in the Cascades. Although gas monitoring is presently not as reliable as seismic and geodetic methods, it can provide important information about subsurface degassing and movement of magma, possible influx of new magma, interaction of magma with groundwater, and the potential for explosive activity of a restless volcano. Systematic measurements of sulfur dioxide emission, using the correlation spectrometer (COSPEC) in air-borne and ground-base modes, have yielded encouraging results at Mount St. Helens, Kilauea, and other volcanoes. For example, gas emission data for sulfur dioxine and carbon dioxine have been used at Mount St. Helens in the prediction of an explosive and a nonexplosive eruption (Casadevall and others, 1983). Continuous monitoring of hydrogen emission at Mount St. Helens, Kilauea, Mauna Loa, and Long Valley is being done routinely utilizing electrochemical sensors and satellite telemetry (Sato and others, 1985).

\section{Fundamental Research}

Fundamental research conducted under the Volcano Hazards Program encompasses diverse topical investigations on volcanic and related phenomena. The goals of the research are: 1. to develop a model to explain, in the context of plate tectonics, the distribution of volcanoes and the occurrence of eruptions in time and space; and 2. to establish a sound theoretical and empirical basis for better understanding volcanic structures and processes and for refining predictive capability, both for eruptions and for related events. Geologic research includes studies of: magma generation, transport, storage, and eruption; evolution of physical and chemical properties of magma and lava; relations between volcanism and seismicity in intraplate and plate-boundary regions; and possible correlations between volcanic activity and other geochemical or geophysical phenomena. 
Hydrologic research is aimed at an improved understanding of the impact of eruptions on surface and ground-water systems and includes studies of: subsurface heat transfer; transport processes, rheology, and erosive effects of mudflows and other debris-laden flows; geomorphology of deposits of unconsolidated volcanic debris; impacts of volcanic debris on the biological and chemical quality of hydrologic systems; and computer modeling of rainfall-runoff events to simulate or document the impact of volcanic eruptions.

U.S. Geological Survey Professional Paper 1250 (Lipman and Mullineaux, 1981), an 844-page volume containing 62 papers describing the 1980 eruptions of Mount St. Helens, includes examples of the spectrum of fundamental research currently being conducted within the program. Other examples of the fundamental research on volcanic phenomena include recent papers by: Ryan and others (1983) on the quantitative modeling of subsidence mechanics of the magma reservoir at Kilauea, Banks and others (1984) on the role of thermal expansion of gases in volcanic processes, and by Wright (1984) on the origin and evolution of Hawaiian tholeiite. A seismic-refraction survey in the Mount Shasta-Medicine Lake region has been completed, as well as a gravity survey of Lassen Volcanic National Park; both of these studies provide subsurface data that constrain the possiblc existence of magma reservoirs. Research on the feasibility of using geoelectric self-potential methods to follow magma movement in the Kilauea rift system is yielding encouraging results. Preliminary analysis of the electrical self-potential data suggest that this technique may provide more advance notice of impending eruptions than seismic and geodetic monitoring methods, which, to date, still remain the most reliable means of detecting short-term precursors of eruptions and determining the location of possible vents.

\section{Emergency-response planning}

As mentioned previously, in 1974 the U.S. Geological Survey was mandated by Congress to provide timely warnings of volcanic and associated hazards. The hazard assessment, monitoring, and research components of the Volcano Hazards Program already discussed produce scientific ad technical data, which then must be disseminated quickly and in a comprehensible manner to public officials concerned with emergency-response planning. To mitigate hazards with a minimum of confusion, the public and responsible government officials must be informed of the seriousness of the hazards so that emergency-response plans can be prepared well in advance of an eruption. Well-coordinated planning and communication with local and regional governments, and with the news media, are essential to achieve 
the proper balance for avoiding undue panic or complacency on the part of the public or the government agencies charged with public safety.

To help achieve these objectives, a three-category system was developed by the USGS for the issue of official notices, watches, and warnings for volcanic and other natural hazards (Federal Register, April 12, 1977). In 1984, a new system was adopted (Federal Register, January 31, 1984), comprising a formal statement called a Hazard Warning, as well as informal notification(s) for forwarding to public officials information regarding hazardous conditions that do not meet the criteria for a hazard warning. In addition, the USGS will establish its own internal emergency-response plans to quickly mobilize its scientific, technical, and administrative resources to respond to volcanic crises as they arise, as, for example, for the Long Valley region of California (U.S. Geological Survey, 1984) described later (p. 440). Various memoranda of understanding have been initiated with other concerned Federal agencies, including the Federal Emergency Management Agency, the U.S. Forest Service, U.S. Park Service, the Federal Aviation Administratin, and the National Weather Service-to coordinate action within the Federal government. In recent years several workshops on volcanic hazards have been held in cooperation with State and local government agencies to focus on specific volcanic hazards and to educate the general public in the areas affected. Moreover, many scientists involved in hazards assessment, volcano monitoring, and fundamental research have been active in giving lectures to various public, school, and civic organizations as part of an informal effort to increase public awareness of volcanic phenomena and associated hazards. Illustrative case histories of the response of hazards-assessment scientists during the Mount St. Helens activity in 1980 are described by Miller and others (1981) and Wesson (1980). According to U.S. Forest Service officials, the land managers of Mount St. Helens, had it not been for the day-to-day hazards assessments and rapid dissemination of information by scientists, the catastrophic events of the May 18, 1980 eruption would have resulted in many more human deaths and injuries.

\section{UPDATE ON SOME CURRENT VOLCANO HAZARDS}

The devastating eruption of Mount St. Helens and related events (May 18, 1980) was the worst volcanic disaster in the recorded history of the United States. About 60 lives were lost during the debris avalanche and lateral blast, and over $\$ 1.1$ billion dollars of property and agricultural damage resulted. Although no major volcanic hazards-related disasters have occurred in the United States since May 1980, three areas require continued intensive monitoring. 


\section{Mount St. Helens Volcano, Washington}

Since May 18, 1980, Mount St. Helens has continued to be intermittently active, producing many minor eruptions; no significant magmatic explosive eruption has occurred since October 1980 (Swanson and others, 1983; Brantley and Topinka, 1984). Beginning June 1980, most of the eruptions included the addition of dacitic magma to the dome growing in the summit crater. For about one year beginning early February 1983, the activity of Mount St. Helens was marked by vigorous, nearly continuous dome growth. Such dome growth was largely endogenous, but visible extrusions onto the surface of the dome occurred in February and May of 1983. The February 1983 activity produced a "pelean" spine that projected $61 \mathrm{~m}$ above the dome surface before collapsing into a heap of rubble in early March.

Since April 1984, Mount St. Helens appears to have returned to its pre1983 pattern of brief dome-biuilding eruptions, lasting only a few days, separated by relatively calm intervals lasting several weeks or months. By October 1984, the composite dome at Mount St. Helens measured about $880 \mathrm{~m}$ long, $830 \mathrm{~m}$ wide, and $250 \mathrm{~m}$ high, comprising an aggregate volume of about $50 \times 10^{6} \mathrm{~m}^{3}$. The average growth rate of the composite dome was about $1.8 \times 10^{6} \mathrm{~m}^{3} /$ month duing $1980-81$ and $0.8 \times 10^{6} \mathrm{~m}^{3} / \mathrm{month}$ in 1982-1983 (Cascades Volcano Observatory, unpublished data).

The present, intermittent activity at Mount St. Helens could persist for several decades, as suggested by its own past eruptive history and by analogy with other historic eruptions (e.g., Santa Maria, Guatemala; Bezymianny, Kamchatka). Thus the continuing activity poses hazards for the foreseeable future. Because the current activity is relatively mild and generally non-explosive, hazards from eruptions are mainly limited to the immediate vicinity of the crater containing the actively growing lava dome. Greater hazards are posed by mudflows and floods related to this activity and to heavy precipitation on the ash and debris-laden slopes; the potential for these hazards has increased with the growth of newly formed lakes created by the debris avalanche of May 1980, which dammed parts of the pre-existing drainage. Because these natural dams are composed of unconsolidated, easily erodible volcanic debris, they are structurally weak and their failure could trigger mudflows and floods. Since 1980, the levels of the lakes impounded by natural dams have gradually risen due to heavy rainfall and runoff typical of the Mount St. Helens region. In the fall of 1982, as a temporary measure, the U.S. Army Corps of Engineers began a massive pumping project at the largest of these impounded lakes (Spirit Lake) to control the rising water level; the USGS and the National Weather Service installed gauges to monitor lake levels and flood-warning systems in the valleys downstream from the lake. 
In mid-1984, the construction of a water-diversion tunnel at the Spirit Lake blockage was begun. The various lake-level control engineering projects have brought workers and equipment into the hazardous zones close to the volcano. To ensure the safety of these workers, CVO scientists must be all the more diligent in monitoring efforts, not only of the volcano itself, but also of the debris-clogged drainage systems that extend many kilometers around it.

\section{Kilauea and Mauna Loa Volcanoes, Hawaii}

Because of their relatively high eruption frequencies, Kilauea and Mauna Loa Volcanoes on the island of Hawaii pose perennial threats to the city of Hilo (approximately 30,000 population), residential developments on the south coast (Puna), and the relatively densely populated resort areas on the west coast (Kona). The volcanic hazard of greatest concern is that of lava flows which periodically overrun residential and agricultural areas downslope from vents along the active rift zones of these two volcanoes.

The 1983 eruption on the Kilauea east-rift zone, which began on January 3 and has continued intermittently to the present (June 1985), has produced spectacular lava fountains as high as $450 \mathrm{~m}$. The fountains have fed lava flows that extend nearly $8 \mathrm{~km}$ down the south flank of the volcano. The eruptions to date have produced more than $300 \times 10^{6} \mathrm{~m}^{3}$ of basaltic lava, mostly of aa type, covering about $80 \mathrm{~km}^{2}$ (unpublished data, Hawaiian Volcano Observatory). Several lava have advanced into the Royal Gardens residential development and adjacent areas near Kalapana, Hawaii, destroying 19 dwellings and covering about 350 house lots (Fig. 4). The January-July 1983 eruptions mark the first destruction of houses since the 1960 lower east-rift zone eruption which destroyed the village of Kapoho. Because of intensive, continuous surveillance of Kilauea, the Hawaiian Volcano Observatory has been able to issue ample warnings of eruptions, and to continuously disseminate accurate information on the progress of the activity and advance of the lava flows, thereby consistently allowing local officials to safely evacuate endangered areas.

Mauna Loa Volcano erupted in July 1975 after a 25-year repose (Lockwood and others, 1976). Fortunately, the 1975 eruption was largely confined to the summit region and posed no hazard to populated and cultivated areas located tens of kilometers downslope. However, the eruptive record of Mauna Loa indicates that larger volume eruptions typically have taken place along one of its two principal rift systems, producing huge, relatively fluid lava flows that advanced great distances in a short time. Such flows in the past have reached several coastal areas, including the city of Hilo, parts of which are built on the 1881 flow. 


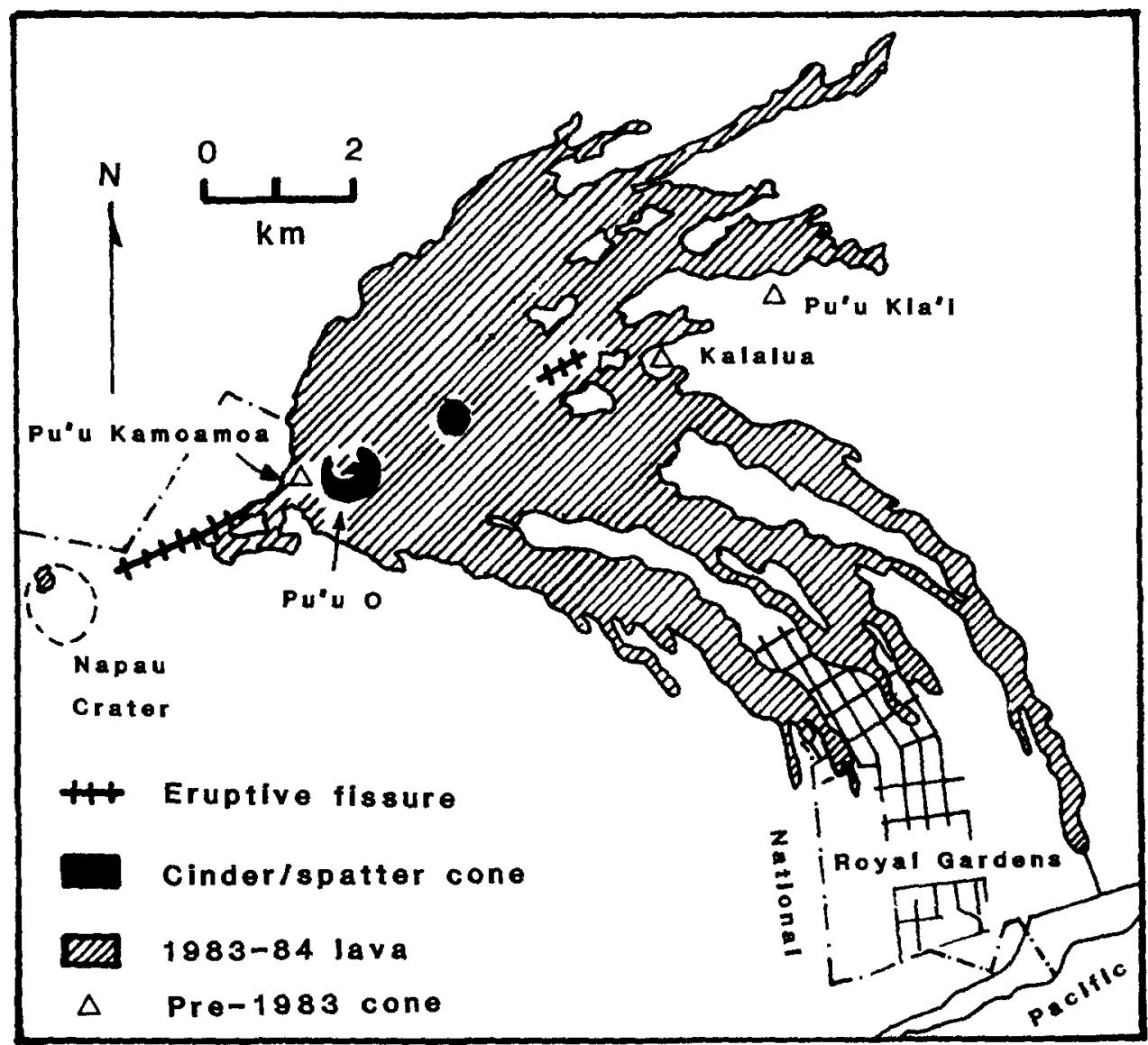

Fig. 4. Sketch map showing the lava flows produced through September 1984 of the Pu'u O'oeruption Kilauea's east-rift zone, which began in January 1983 (Hawaiian Volcano Observatory, unpublished data). The Royal Gardens residential development can be seen in the lower right-hand corner.

In 1980, seismicity at Mauna Loa began to increase gradually, and since 1981 electronic-distance-measurement (EDM) data have shown significant extension of the summit region. The increase in seismicity became even more pronounced in 1983. On the basis of these and other volcano-monitoring data, the Hawaiian Volcano Observatory forecast in September 1983 that "...the probability significantly increases for an eruption of Mauna Loa during the next two years." (Decker and others, 1983; 1984).

The volcano erupted six months later. The eruption began in Mokuaweoweo summit region early on the morning of March 25, 1984, and the vent activity following a very brief excursion down the upper southwestrift, progressively migrated down the northeast-rift zone (Lockwood and others, 1985). Several massive flows-pahoehoe near the vent but changing 
in a short distance to aa-advanced rapidly down the northeast flank of the volcano. Two $25 \mathrm{~km}$-long aa flows (Fig. 5) posed a potential threat to Hilo, but fortunately they stopped about 5 to $10 \mathrm{~km}$ short of the city. Natural stagnation and branching of the flows occurred at about the $1,800 \mathrm{~m}$ elevation, 10 to $15 \mathrm{~km}$ downstream from the vents, resulting in a "self-diversion" process that apparently impeded flow advance. The eruption ended on April 15, after producing an estimated $218 \times 10^{6} \mathrm{~m}^{3}$ of lava, which covered approximately $48 \mathrm{~km}^{2}$ (Lockwood and others, 1985).

\section{Long Valley caldera, eastern California}

Long Valley has been a major center of volcanism for $3.2 \mathrm{~m} . \mathrm{y}$. Widespread basaltic and quartz-latitic eruptions, which dominated the early activity, culminated $0.7 \mathrm{~m} . \mathrm{y}$. ago in climactic rhyolite ash-flow eruptions that produced $600 \mathrm{~km}^{3}$ of Bishop Tuff and resulted in the formation of Long Valley caldera, a $17 \times 30 \mathrm{~km}$ elliptical depression on the east front of the Sierra Nevada. Since that time, lesser eruptions, mainly extrusion of rhyolite domes and flows, have been confined to the caldera floor and moat

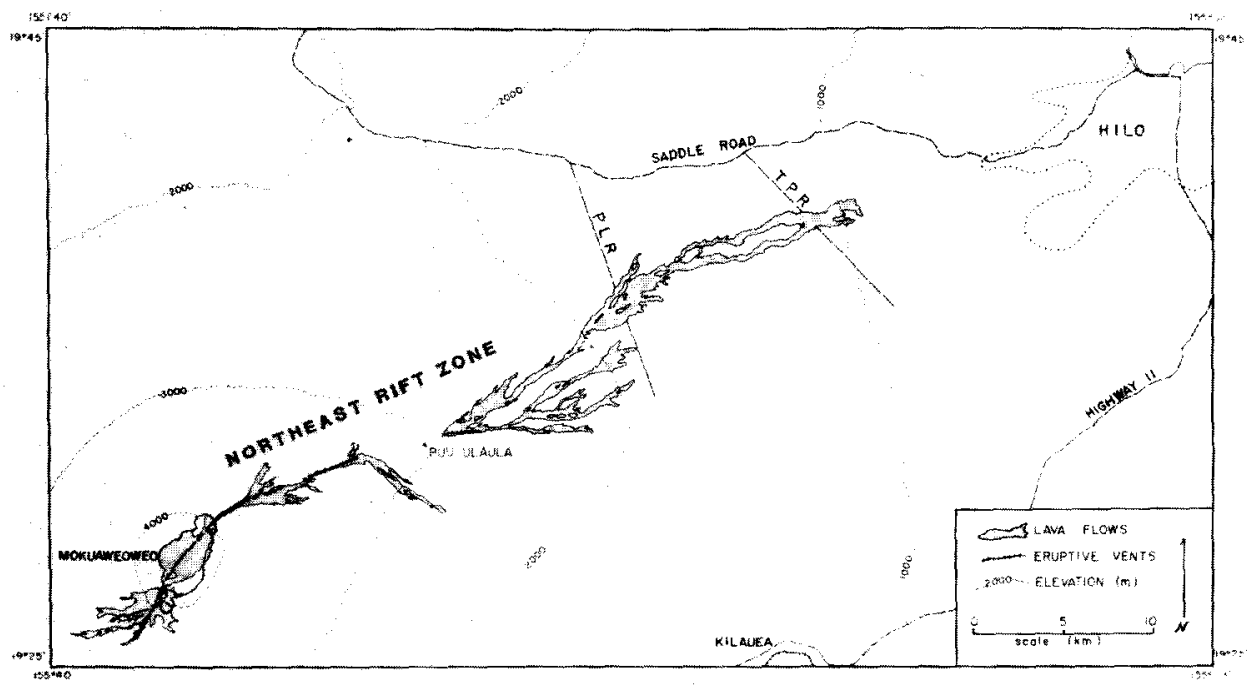

Fig. 5. Distribution of vent fissures and lava flows, March-April 1984 eruption of Mauna Loa Volcano, Hawaii; PLR: Power Line Road, TPR: Tree Planting Road. (From Lockwood and others, 1985, Figure 5). 
(Bailey and others, 1976). The youngest of these post-caldera eruptions from the residual Long Valley magma reservoir occurred 100,000 years ago, although younger eruptions from other nearby magmatic sources (e.g., Inyo-Mono Craters) have occurred as recently as 550 years ago (Miller, 1984). A crude periodicity of about 200,000 years for eruptions derived from Long Valley magma reservoir would suggest that future eruptions, if they should occur, might not be expected for another 100,000 years. However, recent unusual seismicity and ground uplift within the caldera has raised concern that eruptions might occur much sooner.

On May 25, 1980, the Long Valley area was rocked by an unusual sequence of earthquakes, which included four magnitude- 6 shocks within a period of 48 hours, accompanied and followed by thousands of earthquakes of lesser magnitude (Bailey, 1982). Since then, lesser swarms, commonly accompanied by spasmodic tremor (Ryall and Ryall, 1983), have continued sporadically within the south moat of the caldera. In January 1983, the area experieced a second major swarm, which included three shocks greater than magnitude 5. Since May 1983, seismicity has declined significantly, but occasional minor swarms continue in the south moat of the caldera, indicating that the activity has not ceased entirely.

Initially these earthquakes were considered to be tectonic in origin, but in late 1980 it was discovered that the quakes were accompanied by uplift of the resurgent dome within Long Valley caldera (Savage and Clark, 1982). This discovery, combined with the fact that the dome is underlain by a magma reservoir at depths of 7-8 km (Hill, 1976; Steples and Iyer, 1976; Ryall and Ryall, 1981), suggested that renewed inflation of the reservoir might, at least in part, be responsible for the unusual seismicity. Intensive seismic, geodetic, geophysical, geochemical and hydrologic monitoring and research by the USGS and other organizations since 1982 strongly suggests that the reservoir has been inflated by renewed magma influx $\left(0.2 \mathrm{~km}^{3}\right)$ and has raised concern that an eruption could occur sooner than might be expected on the basis of previous periodicity. Of particular concern is the possibility that a major tectonic earthquake in the region, for which there is some basis for anticipation (Wallace and others, 1984), might unexpectedly trigger an eruption from the partially recharged magma chamber.

On the basis of the above activity and on preliminary volcanic-hazards assessment (Miller and others, 1982), the USGS issued an official Notice of Potential Volcanic Hazard in May 1982. In addition, several workshops (e.g., Martin and Davis, 1982) and public information meetings were organized in concert with other Federal, state, and local agencies and officials in an effort to help the inhabitants in the nearby towns of Bishop, Mammoth Lake, June Lake, and Lee Vining to develop emergencyresponse plans in the event of a future eruption. Under the new (1984) 


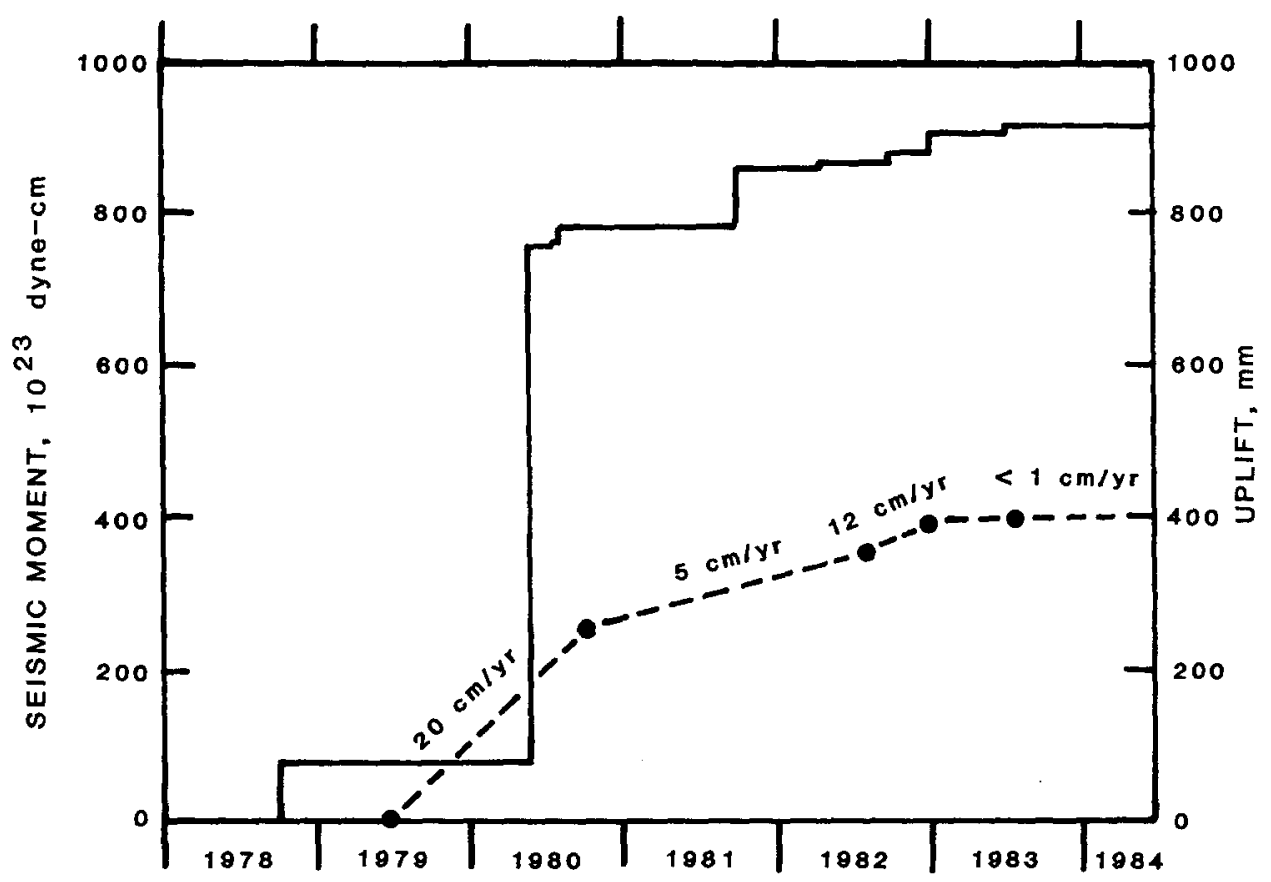

Fig. 6. Summary of seismic activity and inflation of the Long Valley resurgent dome in terms of cumulative seismic moment (solid line) for earthquakes and elevation of a benchmark (dashed line) on the south flank of dome (modified from Hill and others, 1984, Figure 2).

system for issuing statements about geologic hazards, the reduced activity at Long Valley would not warrant a Hazards Warning designation. Accordingly, the Notice of Potential Volcanic Hazard was withdrawn, but Dr. Dallas Peck, Director of the USGS, emphasized in a press release on July 26,1984 , that "...the area must still be recognized as having the potential for volcanic activity." The USGS is continuing its intensified monitoring of Long Valley.

\section{SUMMARY}

Prior to 1980, the U.S. Volcano Hazards Program was a rather modest effort largely focused on the monitoring of the active Hawaiian volcanoes by the Hawaiian Volcano Observatory, but it included limited studies leading to volcanic-hazards assessments of Mount St. Helens and some other Cascade volcanoes. After the reawakening of Mount St. Helens in March 1980 , and especially following the catastrophic eruption of May 18, the Volcano Hazards Program was considerably expanded because of increased awareness of the potential of eruptions and associated hazards within con- 
terminous United States. At present, the U.S. Geological Survey operates two fully equipped volcano observatories-HVO and CVO- and is continuing intensive monitoring at Long Valley, California.

Significant progress has been made in volcano monitoring and volcanichazards assessment. At Mount St. Helens, all of the eruptions since June 1980 have been predicted tens of minutes to, more generally, hours or days in advance. Some of the dome-building eruptions were predicted even three weeks in advance. The predictive capability for Mount St. Helens for the current intermittent activity is unprecedented for a science as young as volcanology. Progress has been made in the measurement of volcanic gas emission as a monitoring tool at Mount St. Helens and some other Cascades volcanoes, at Kilauea and Mauna Loa, and at Long Valley. Preliminary volcanic-hazards assessments are now available for many of the Cascade and Hawaiian volcanoes and for Long Valley caldera, but most will require updating as more comprehensive data become available.

Although the present Volcano Hazards Program on the whole has been successful and productive, greater emphasis on long-term fundamental research on magmatic phenomena and on the large pre-Holocene volcanic systems is needed to understand better the formation and evolution of such systems. Since the dawn of civilization, mankind fortunately has not been subjected to volcanic cataclysms of the scale that produced Yellowstone caldera. Research on caldera-forming processes must be intensified if there is to be any hope of gaining insights into the precursors of caldera formation and thereby becoming better prepared to cope with such eruptions should they occur.

\section{ACKNOWLEDGMENTS}

We both have served as the Coordinator of the Volcano Hazards Program in recent years. During our tenure, we benefited greatly from enthusiastic and stimulating discussions with our colleagues in the U.S. Geological Survey, University of Washington, and other organizations on the challenges and scientific results of the studies conducted under the program, currently coordinated by Dr. L. J. Patrick Muffler in the Office of Earthquakes, Volcanoes, and Engineering in Menlo Park, California. The staffs of the Hawaiian and Cascades Volcano Observatories kindly allowed us to use unpublished data. Special thanks go to Robert W. Decker, Marianne Guffanti, Robert G. Luedke, and Christopher G. Newhall-all of the U.S. Geological Survey-for their constructive criticism and helpful suggestions on earlier drafts of this paper. 


\section{REFERENCES}

Bailey, R. A., 1982, Mammoth Lakes earthquakes and ground uplift: Precursors to possible volcanic activity?: U.S. Geological Survey Yearbook, Fiscal Year 1982, p. 4-13.

Bailey, R. A., Dalrymple, G. B., and Lanphere, M.A., 1976. Volcanism, structure, and geochronology of Long Valley Caldera, Mono County, California: Journal of Geophysical Research, v. 81, no. 5, p. $725-744$.

Bailey, R. A., Beauchemin, P. R., Kapinos, F. P., and Klick, D. W., 1983. The Volcano Hazards Program: Objectives and Long-Range Plans: U.S. Geological Survey Open-File Report 83-400, $33 \mathrm{p}$.

Banks, N. G., Greenland, L. P., and Pollard, D. D., 1984. Thermal expansion of entrained and magmatic gases-Implications for volcanic eruption, dike propagation, and tremor: Geology (in press).

Brantley, Steve, and Topinka, Lyn, 1984, editors, Volcanic studies at the U.S. Geological Survey's David A. Johnston Cascades Volcano Observatory: Earthquake Information Bulletin, v. 16, no. 2, p. 44-122.

Casadevall, T. J., Rose, W. I., Gerlach, T., Greenland, L. P., Ewert, J., Wunderman, R., and Symons, R., 1983. Gas emissions and the eruptions of Mount St. Helens through 1982: Science, v. 221, no. 4618 , p. 1383-1385.

Christiansen, R. L., 1984, Yellowstone magmatic evolution: Its bearing on understanding large-volume explosive volcanism. In: Boyd, J. R., editor, Explosive Volcanism: Inception, Evolution, and Hazards, National Academy Press, Washington, D.C., p. 84-95.

Crandell, D. R., 1975. Assessment of volcanic risk on the island of Oahu, Hawaii: U.S. Geological Survey Open-File Report OF 75-287, 18 p.

Crandell, D. R., 1980. Recent eruptive history of Mount Hood, Oregon, and potential hazards from future eruptions, U.S. Geological Survey Bulletin 1492, 81 p.

Crandell, D. R., 1983. Potential hazards from future volcanic eruptions of the island of Maui, Hawaii: U.S. Geological Survey Map I-1442.

Crandell, D. R. and Mullineaux, D. R., 1967. Volcanic hazards at Mount Rainier, Washington. U.S. Geological Survey Bulletin 1238, $26 \mathrm{p}$.

Crandell, D. R., and Mullineaux, D. R., 1978. Potential hazards from future eruptions of Mount St. Helens Volcano, Washington: U.S. Geological Survey Bulletin 1383-C, 26 p.

Crandell, D. R., and Mullineaux, D. R., 1975. Technique and rationale of volcanic-hazards appraisals in the Cascade Range, northwestern United States: Environmental Geology, v. 1, no. 1, p. 23-32.

Crandell, D. R., Mullineaux, D. R., and Rubin, Meyer, 1975. Mount St. Helens Volcano: Recent and future behavior: Science, v. 187, no. 4175, p. 438-441.

Crandell, D. R., Mullineaux, D. R., and Miller, C. D., 1979. Volcanic-hazard study in the Cascade Range of the western United States. In: Sheets, P. D., and Grayson, D. R., eds., Volcanic Activity and Human Ecology: New York, Academic Press, p. 195-219.

Decker, R. W., and Christiansen, R. L., 1984. Explosive eruptions of Kilauea Volcano, Hawaii. In: Boyd, J. R., editor, Explosive Volcanism: Inception, Evolution, and Hazards, National Academy Press, Washington, D.C., p. 122-132.

Decker, R. W., Koyanagi, R. Y., Dvorak, J. J., Lockwood, J. P., Okamura, A. T., Yamashita, K. M., and Tanigawa, W. R., 1983. Seismicity and surface deformation of Mauna Loa Volcano, Hawaii: EOS, v. 64 , no. 37 , p. $545-547$.

Decker, R. W., Koyanagi, R. Y., Dvorak, J. J., Lockwood, J. P., Okamura, A. T., Yamashita, K. M., and Tanigawa, W. R., 1984. Seismicity and grand deformation of Mauna Loa Volcano, Hawaii: 27th International Geological Congress, August 4-14, 1984, Abstracts Volume 4, p. 59 (Abstract).

Eaton, G. P., Christiansen, R. L., Iyer, H. M., Pitt, A. M., Mabey, D. R., Blank, H. R., Jr., Zietz, I., and Gettings, M. E., 1975. Magma beneath Yellowstone National Park, Science, v. 188, p. 787-796. 
Federal Register, 1977, Warning and preparedness for geologic-related hazards: proposed procedures. vol. 42, no. 70, p. 19292-19296, April 12, 1977.

Federal Register, 1984. Revision of terminology for geologic hazard warnings, v. 49, no. 21, p. 3938-3939, January 31, 1984.

Foxworthy, B. L. and Hill, Mary, 1982, Volcanic eruptions of 1980 at Mount St. Helens: The first 100 days: U.S. Geological Survey Professional Paper 1249, $125 \mathrm{p}$.

Greenland, L. P., 1984. Gas composition of the January 1983 eruption of Kilauea Volcano, Hawaii: Geochim. et Cosmochim. Acta, v. 48, p. 193-198.

Hill, D. P., 1976. Structure of Long Valley caldera, California, from a seismic refraction experiment: Jour. Geophys. Res., v. 81, no. 5, p. 745-753.

Hill, D. P., Ryall, A. S., and Bailey, R. A., 1984. Active tectonic and magmatic processes beneath Long Valley caldera, eastern California: A summary: U.S. Geological Survey Open-File Report 84-939, p. 4-23.

Hill, D. P., Wallace, R. E., and Cockerham, R. S., 1985. Review of evidence on the potential for major earthquakes and volcanism in the Long Valley-Mono Craters-White Mountains regions of eastern California: Earthquake Prediction Research (in press)

Hyde, J. H., and Crandell, D. R., 1978. Post-glacial volcanic deposits at Mount Baker, Washington, and potential hazards from future eruptions U.S. Geological Survey Profesional Paper 1022-C, $17 \mathrm{p}$.

Iyer, H. M., 1975. Anomalous delays of teleseismic $P$ waves in Yellowstone National Park, Nature, v. 253, p. 425-427.

Kienle, Juergen, and Swanson, S. E., 1983. The hazards of Augustine: The Northern Engineer, v. 15 , no. 3, p. $10-37$.

Lipman, P. W., and Mullineaux, D. R., 1981, editors, The 1980 eruptions of Mount St. Helens, Washington: U.S. Geological Survey Professional Paper 1250, 844 p.

Lockwood, J. P., Koyanagi, R. Y., Tilling, R. I., and Holcomb, R. T., 1976. Mauna Loa threatening: Geotimes, v. 21, no. 6, p. 12-15.

Lockwood, J. P., Banks, N. G., Dvorak, J., English, T., Greenland, L. P., Jackson, D. B., Johnson, D., Koyanagi, R. Y., McGee, K., Okamura, A. T., Rhodes, M., Sato, M., and Tanigawa, W., 1985. The 1984 eruption of Mauna Loa Volcano, Hawaii: EOS, (in press).

Martin, R. C., and Davis, J. F., 1982, editors, Status of volcanic prediction and emergency response capabilities in volcanic hazards zones of California: Special Publication 63, California Dept. of Conversation, Division of Mines and Geology, $275 \mathrm{p}$. (Proceedings of a workshop on volcanic hazards, December 3-4, 1981, Sacramento, California).

McBirney, A. R., 1968. Petrochemistry of the Cascade andesite cones. In: Dole, H. M., editor, Andesite Conference Guidebook Oregon Department of Geology and Mineral Industries Bulletin 62, p. $101-107$.

McBirney, A. R., 1978. Volcanic evolution of the Cascade Range: Ann. Rev. Earth Planet. Sci., v. 6, p. $437-456$.

Miller, C. D., 1980. Potential hazards from future eruptions in the vicinity of Mount Shasta volcano, northern California: U.S. Geological Survey Bulletin 1503, $43 \mathrm{p}$.

Miller, C. D., Mullineaux, D. R., and Crandell, D. R., 1981, Hazards assessments at Mount St. Helens. In: Lipman, R. W., and Mullineaux, D. R., editors, The 1980 eruptions of Mount St. Helens, Washington: U.S. Geological Survey Professional Paper 1250, p. 789-802.

Miller, C. D., Mullineaux, D. R., Crandell, D. R., and Bailey, R. A., 1982. Potential hazards from volcanic eruptions in the Long Valley-Mono Lake area, east-central California and southwest Nevada- A preliminary assessment: U.S. Geological Survey Circular $877,10 \mathrm{p}$.

Miller C. D., 1984. Holocene eruptions at the Inyo Volcanic Chain, California-Implications for possible eruptions in Long Valley caldera: U.S. Geological Survey Open-File Report 84- (in press).

Mullineaux, D. R., and Peterson, D. W., 1974. Volcanic hazards on the island of Hawaii: U.S. Geological Survey Open-File Report OF 74-234, 61 p. 
Newhall, C. G., 1982. A method for estimating intermediate and long-term risks from volcanic activity, with an example from Mount St. Helens, Washington: U.S. Geological Survey Open-File Report $82-396,59 \mathrm{p}$.

Pelton, J. R., and Smith, R. B., 1979. Recent crustal uplift in Yellowstone National Park: Science, v. 206, p. 1179-1182.

Ryall, Florianna, and Ryall, A. S., 1981. Attenuation of $P$ and $S$ waves in a magma chamber in Long Valley caldera, California: Geophys. Res. Letters, v. 8, p. 557-560.

Ryall, A. S., and Ryall, Florianna, 1983. Spasmodic tremor and possible magma injection in Long Valley caldera, eastern California: Science, v. 219, p. 1432-1433.

Ryan, M. P., Blevins, J. Y. K., Okamura, A. T., and Koyanagi, 1983. Magma reservoir subsidence mechanics: Theoretical summary and application to Kilauea Volcano, Hawaii: Journal of Geophysical Research, v. 88, no. B5, p. 4147-4187.

Sato, Motoaki, McGee, K. A., Sutton, A. J., Casadevall, T. J., Steinthorsson, S., and Johannesson. A. E. 1985. Monitoring of hydrogen for prediction of volcanic eruptions and earthquakes: Italian-Soviet Symposium on the Geochemical Surveillance of Volcanoes and Earthquakes. Proceedings volume (in press).

Savage, J. C., and Clark, M. M., 1982. Magmatic resurgence in Long Valley. California: Possible cause of the 1980 Mammoth Lakes earthquakes: Science, v. 217, p.531-533.

Simkin, T., Siebert, L., McClelland, L., Bridge, D., Newhall, C., and Latter, J. H., 1981. Volcanoes of the World: A regional directory, gazatteer, and chronology of volcanism during the last 10,000 years: Hutchison Ross Publishing Company, Stroudsburg, Pennsylvania, $232 \mathrm{p}$.

Smith, R. B., and Christiansen, R. L., 1980. Yellowstone Park as a window on the Earth's Interior, Scientific American, v. 242, n. 2, p. 104-117.

Smith, R. L., and Luedke, R. G., 1984. Potentially active volcanic lineaments and loci in western conterminous United States. In: Boyd, J. R., editor, Explosive Volcanism: Inception, Evolution, and Hazards, National Academy Press, Washington, D.C., p. 47-66.

Steeples, D. W., and Iyer, H. M., 1976. Low-velocity zone under Long Valley as determined from teleseismic events: Jour. Geophys. Res., v. 81, no. 5, p. 849-860.

Swanson, D. A., 1982. Volcanic studies in the Pacific Northwest, 1879-1979. In: Leviton, A. E., Rodda, P. U., Yochelson, Ellis, and Aldrich, M. L., editors, Frontiers of Geological Exploration of western North America: Pacific Division of AAAS, Allen Press, Lawrence, Kansas, $48 \mathrm{p}$.

Swanson, D. A., 1983. Forecasts and predictions: EOS, v. 64, no. 28, p. 452.

Swanson, D. A., Casadevall, T. J., Dzurisin, D., Malone, S. D., Newhall, C. G., and Weaver, C. S., 1983. Predicting eruptions at Mount St. Helens, June 1980 through December 1982: Science, v. 221, n. 4618 , p. $1369-1376$.

Swanson, D. A., Casadevall, T. J., Dzurisin, D., Malone, S. D., Newhall, C. G., and Weaver, C. S., 1984. Forecasts and predictions at Mount St. Helens USA: 27th International Geological Congress, Moscow, August 4-12, 1984. Reports Volume 6, p. 119-135.

Tilling, R. I., and Bailey, R. A., 1984a. Volcano Hazards Program in the USA: 27th International Geological Congress, Moscow, August 4-14, 1984. Abstracts Volume 9, p. 315-316 (Abstract).

Tilling, R. I., and Bailey, R. A., 1984b. Volcano Hazards Program in the USA: 27th International Geological Congress, Moscow, August 4-14, 1984. Reports Volume 6, p. 106-118.

U.S. Geological Survey, 1984. USGS Response plan for volcanic hazards in the Long Valley CalderaMono Craters area, California: U.S. Geological Survey Open-File Report 84-500, 12 p.

Wallace, R. E., Hill, D. P., Ryall, A. S., and Cockerham, R. S., 1983. Potential for large earthquakes in central Nevada-eastern California seismic belt: Earthquake Notes, v. 54, p. 4647 (Abstract).

Wesson, R. L., 1980. The eruption of Mount St. Helens: Entering the era of real-time geology. In: U.S. Geological Survey Yearbook Fiscal Year 1980, p. 6-15.

Wright, T. L., 1984. Origin of Hawaiian tholeite: a metasomatic model: Jour. of Geophys. Res., v. 89. no. B5, p. 3233-3252. 